\title{
Outcomes in patients with aortic regurgitation treated according to recommendations - a single center study
}

\section{(D)Marija Mance*, (i) Vlatka Rešković Lukšic, \\ DBlanka Glavaš, (1) Martina Lovrić Benčić, \\ DJoško Bulum, (iDZvonimir Ostojić, (D) Jadranka Šeparović Hanževački}

University of Zagreb School of Medicine, University Hospital Centre Zagreb, Zagreb, Croatia

RECEIVED:

February 28, 2019

ACCEPTED:

March 24, 2019

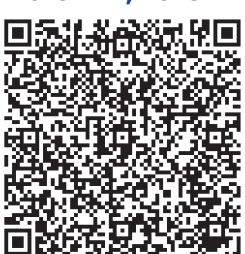

KEYWORDS: aortic regurgitation, treatment.

CITATION: Cardiol Croat. 2019;14(3-4):84. | https://doi.org/10.15836/ccar2019.84

*ADDRESS FOR CORRESPONDENCE: Marija Mance, Klinički bolnički centar Zagreb, Kišpatićeva 12, HR-10000 Zagreb, Croatia. / Phone: +385-99-7742-627 / E-mail: marija.brestovac@gmail.com

ORCID: Marija Mance, https://orcid.org/0000-0003-1542-2890 • Vlatka Rešković Lukšić, https://orcid.org/0000-0002-4721-3236 Blanka Glavaš, https://orcid.org/0000-0003-1134-4856 • Martina Lovrić Benčić, https://orcid.org/0000-0001-8446-6120 Joško Bulum, https://orcid.org/0000-0002-1482-6503 • Zvonimir Ostojić, https://orcid.org/0000-0003-1762-9270 Jadranka Šeparović Hanževački, https://orcid.org/0000-0002-3437-6407

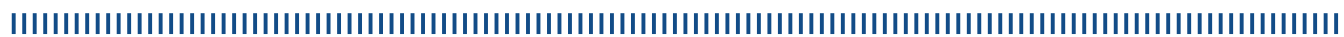

Introduction: Age and gender may influence the incidence of aortic regurgitation (AR) and its severity. Significant aortic regurgitation (sAR) is often treated surgically especially when symptomatic or when systolic function declines. ${ }^{1-3}$ The aim of this study was to evaluate the outcomes in patients with sAR according to treatment strategy, age and gender differences in our study population.

Methods: In this retrospective descriptive single-center study an overall of 107 patients (22 female, 85 male) with significant AR in the last 5 years were analyzed. Patients were treated according to valid recommendations, surgically (SUR) or conservatively (CON), except for 5 patients who refused surgery. Baseline and follow up (FU) data (AR severity, left ventricular ejection fraction (LVEF), ascending aorta diameter (AA), treatment, comorbidities and major adverse cardiac events during FU), from documented medical history and digital imaging data were collected and analyzed. Additional sub-analysis was performed according to sex and age differences (above vs. below the age of 50). For statistical analysis a Chi-Square test was used.

Results: In the overall study population, during an average FU of 3.8 years, 16 patients (15\%) developed major adverse cardiac events (MACE) with no statistically significant difference between gender $(p=0.846)$. Forty-six (43\%) patients were surgically treated (87\% male, $13 \%$ female) and 61 (54\%) conservatively. LVEF did not worsen in FU period (54.1\%, vs. 53.8\%). In SUR, median age was 54 years, severe AR was present in $93 \%$, incidence of MACE was $21.7 \%, 80.4 \%$ patients were symptomatic and $14.5 \%$ had dilatation of AA more than $50 \mathrm{~mm}$. In CON, MACE was present in $9.8 \%$ during FU ( $p=0.87)$, median age was 64 years. Intermediate AR (48\% vs $6.5 \%$ ) and AA from $40-49 \mathrm{~mm}$ ( $80 \mathrm{vs} 35 \%$ ) was present more frequently as well as arterial hypertension (82 vs $70 \%$ ) and chronic renal disease (23.2 vs 16.6\%). The incidence of MACE was not found to be age-related $(\mathrm{p}=0.426)$.

Conclusion: In patients with sAR treated by either surgery or medication therapy only, during 3.8 years of FU, LVEF remained unchanged, while incidence of MACE was not found to be related to treatment strategy nor gender. In surgically treated patients, as expected, AR was more severe and AA was more dilated, while neither age nor gender had an impact on the incidence of MACE. $\square$ Cardiologia Croatica 2019;14(3-4):84.
10. hrvatski dvogodišnji ehokardiografski kongres s međunarodnim sudjelovanjem $10^{\text {th }}$ Croatian Biennial Echocardiography Congress with International Participation Poreč, 16. do 18.5.2019.

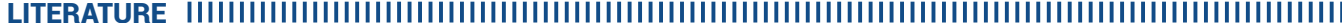

1. Singh JP, Evans JC, Levy D, Larson MG, Freed LA, Fuller DL, et al. Prevalence and clinical determinants of mitral, tricuspid, and aortic regurgitation (the Framingham Heart Study). Am J Cardiol. 1999 Mar 15;83(6):897-902. https://doi.org/10.1016/S0002-9149(98)01064-9

2. de Meester C, Gerber BL, Vancraeynest $D$, Pouleur AC, Noirhomme P, Pasquet A, et al. Early surgical intervention versus watchful waiting and outcomes for asymptomatic severe aortic regurgitation. J Thorac Cardiovasc Surg. 2015 Nov;150(5):1100-8. https://doi.org/10.1016/j.jtcvs.2015.07.053

3. McConkey HZ, Rajani R, Prendergast BD. Improving outcomes in chronic aortic regurgitation: timely diagnosis, access to specialist assessment and earlier surgery. Heart. 2018 May:104(10):794-795. https://doi.org/10.1136/heartjnl-2017-312518 